\title{
Auto-induction expression of human consensus interferon-alpha in Escherichia coli
}

\author{
Nawal Abd EL-Baky ${ }^{1}$, Mustafa H Linjawi ${ }^{2}$ and Elrashdy M Redwan ${ }^{1,3^{*}}$
}

\begin{abstract}
Background: Isopropyl- $\beta$-D-1-thiolgalactopyranoside (IPTG)-inducible expression of recombinant proteins in E. coli is commonly used and effective. Nevertheless, unintended induction was encountered as a problem when using these bacterial expression systems, generating cultures that give reduced or variable protein yields. Auto-induction allows for production of much higher target protein yield and cell mass than conventional procedures using induction with IPTG without monitoring cell growth then adding IPTG at the appropriate cell density. This method involves special media recipes that promote growth to high density and automatically induce expression of target protein from T7 promoter. Consensus interferon is a synthetic artificially engineered interferon having an amino acid sequence that is a rough average of the sequences of all natural human alpha interferon subtypes and has greater potency than other interferons even the pegylated versions. The purpose of this study was high-level expression of human consensus interferon-alpha (cIFN-a) in E. coli using an auto-induction protocol. The cIFN-a gene was cloned into pET101/D-TOPO expression vector under the T7 promoter transcriptional regulation. Expression was optimized with respect to temperature and length of incubation in shake flask cultures. The antiviral potency and anticancer activity of cIFN-a were evaluated in comparison to IFN-a2a.
\end{abstract}

Results: The expressed cIFN-a protein in auto-induction T7 system was found mostly in soluble fraction of the cell lysate (about $70 \%$ of yield in total cell lysate) after lowering incubation temperature to $25^{\circ} \mathrm{C}$ or $30^{\circ} \mathrm{C}$. Protein expression was maximal after $24 \mathrm{~h}$ incubation at $25^{\circ} \mathrm{C}$ or $30^{\circ} \mathrm{C}$. After purification via single-step chromatography using DEAE-Sepharose, the yield was $270 \mathrm{mg} / \mathrm{L}$ in shake flask E. coli cultures which is much higher than IPTG-inducible T7 expression system and other systems according to available data. The synthesized cIFN-a was biologically active as confirmed by its anticancer and antiviral effects and was significantly more potent than IFN-a2a.

Conclusions: The auto-induction process was reliable and convenient for production of cIFN-a protein in E. coli, and can be adapted for large-scale therapeutic protein production.

Keywords: Auto-induction, Human consensus interferon-alpha, IPTG-inducible expression system, T7 expression system

\section{Background}

Interferons (IFNs) are cytokines secreted by vertebrates' cells when stimulated by viruses and several other agents $[1,2]$. This family of glycoproteins exhibits antiviral, antiproliferative and immunomodulation functions [3]. Based on their receptor specificity, structure and functional properties, IFNs are divided into 3 major groups (type I

\footnotetext{
* Correspondence: redwan1961@yahoo.com

${ }^{1}$ Therapeutic and Protective Proteins Laboratory, Protein Research

Department, Genetic Engineering and Biotechnology Research Institute, City for Scientific Research and Technology Applications, New Borg EL-Arab, 21934 Alexandria, Egypt

${ }^{3}$ Biological Sciences Department, Faculty of Science, King Abdulaziz

University, P.O. Box 80203, Jeddah 21589, Saudi Arabia

Full list of author information is available at the end of the article
}

(IFN- $\alpha$ and IFN- $\beta$ ), type II (IFN- $\gamma$ ) and type III (IFN- $\lambda)$ ) [4]. Consensus interferon is a synthetic type of IFN- $\alpha$ containing 166 amino acids that was engineered to comprise the most frequently observed amino acids among all natural non-allelic IFN- $\alpha$ subtypes in humans [5] to form a consensus molecule. In vitro studies have shown that consensus interferon yields more potent antiviral and antiproliferative effects than other standard interferons (IFN- $\alpha 2 a$, IFN- $\alpha 2 b$, and pegylated versions) [6]. This artificial interferon was used in combination with ribavirin to treat nonresponder population or relapsers to a previous interferon regime $[7,8]$.

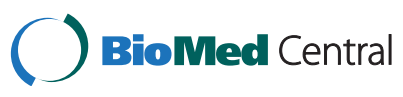

(C) 2015 EL-Baky et al.; licensee BioMed Central. This is an Open Access article distributed under the terms of the Creative Commons Attribution License (http://creativecommons.org/licenses/by/4.0), which permits unrestricted use, distribution, and reproduction in any medium, provided the original work is properly credited. The Creative Commons Public Domain Dedication waiver (http://creativecommons.org/publicdomain/zero/1.0/) applies to the data made available in this article, unless otherwise stated. 
There have been many efforts to express the artificial gene of consensus interferon in E. coli [9-12]. Fieschko and Ritch [10] developed a semisynthetic medium for the production of human consensus interferon- $\alpha$ (IFNalfacon-1) via tightly regulated expression system and a controlled feeding schedule. They obtained yields up to $7.6 \times 10^{12} \mathrm{U}$ per liter of fermentation broth, however this result was not reproducible. Curless et al. [12] designed cyclic, two-stage fed-batch cultivation schemes for the expression of human consensus IFN- $\alpha$ under the $\lambda \mathrm{P}_{\mathrm{L}}$ promoter transcriptional control. They achieved a yield of $5.5 \mathrm{~g} / \mathrm{L}$ interferon at a cell density of $68 \mathrm{~g}$ of dry cell weight $(\mathrm{DCW}) / \mathrm{L}$ but maintaining two reactors may have restricted the use of this design. We have previously reported heat-inducible expression of cIFN- $\alpha$ protein in $E$. coli with a $\lambda \mathrm{P}_{\mathrm{L}}$ promoter system [13]. Most of the expressed protein aggregated into inclusion bodies, therefore needed in vitro refolding. After refolding and purification, the yield was $70 \mathrm{mg} / \mathrm{L}$ in shake flask cultures.

The T7 system comprising the T7 promoter and phage T7 RNA polymerase is one of the most widely used expression systems [14]. In host $E$. coli strains such as BL21 (DE3), T7 RNA polymerase is expressed under the control of the IPTG-inducible lacUV5 promoter. Expression of the target protein from cloned gene is controlled by the T7 promoter. This promoter is recognized specifically by T7 RNA polymerase. After sufficient amount of T7 RNA polymerase is produced, it binds to the T7 promoter and transcribes the gene of interest. Various recombinant proteins were overexpressed in E. coli using this system. A problem in using this expression system is that there is always some basal expression of T7 RNA polymerase from the lacUV5 promoter even in the absence of inducer [14]. If the target protein is toxic to the $E$. coli host, basal expression of the target gene possibly will result in plasmid instability and/or cell death. To reduce basal expression, a lac operator sequence (a binding site for lac repressor) is placed downstream of the T7 promoter, constructing a T7lac promoter [15]. The lac repressor binds to the lac operator and functions to further repress T7 RNA polymerase-induced basal transcription of the target gene in BL21 (DE3) cells. In addition, IPTG induction frequently leads to formation of inclusion bodies [16].

Recently, Studier [17] developed an auto-induction process for production of recombinant proteins under the control of the T7 promoter in E. coli. Auto-inducing media are made from a well-balanced combination of different carbon sources and other essential nutrients, allowing cultures to grow to high cell densities, and support high-level expression of the target protein. These media contain glucose, which promotes fast cellular growth in the early stages of the culture, while also preventing uptake and metabolism of inducing sugar. Lactose is also present in these media, and is consumed after glucose exhaustion, inducing recombinant protein expression. To achieve sustained growth during the induction phase, glycerol is provided in auto-inducing media together with lactose. Formulation of auto-inducing media achieved higher recombinant protein yields than those using IPTG as inducer [17]. The aim of this work was expression of cIFN- $\alpha$ protein in $E$. coli by auto-induction procedure in shake flasks for the first time, purification of recombinant cIFN- $\alpha$ and determination of its antiproliferative and antiviral activities.

\section{Methods}

\section{Cloning of the CIFN- $\alpha$ gene into pET101/D-TOPO expression} vector

The coding sequence of the synthetic cIFN- $\alpha$ gene was assembled and amplified by two-step PCR-based gene synthesis method using long (45-50 nucleotides) overlapped primers and GC-Rich PCR system (Roche Molecular Biochemicals, Mannheim, Germany) as described previously $[13,18]$. The blunt-ended PCR product of cIFN- $\alpha$ gene was cloned into the pET101/D-TOPO vector (Invitrogen, Carlsbad, USA) as recommended by the manufacturer to yield pET-cIFN $\alpha$ expression construct. To allow pET directional TOPO cloning, the forward PCR primer used in amplification of the cIFN- $\alpha$ gene was designed to contain the sequence, CACC, at the $5^{\prime}$ end of the primer directly precedes an initiation ATG codon. The 4 nucleotides, CACC, base pair with the overhang sequence, GTGG, in pET-TOPO vector. A stop codon (TAA) was included in the reverse primer. The resulting $\mathrm{pET}$-cIFN $\alpha$ plasmid was transformed into BL21-CodonPlus (DE3) chemically competent $E$. coli (Stratagene, Heidelberg, Germany) for protein expression regulated by the $\mathrm{T} 7$ promoter. Then the cells were plated onto Luria Bertani (LB) agar plates containing ampicillin $(100 \mu \mathrm{g} / \mathrm{ml})$. Plasmid was purified using Miniprep kit (Qiagen, Hilden, Germany) from overnight culture of picked single colonies then

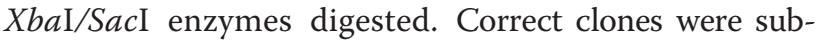
jected to nucleotide sequencing.

\section{Auto-induction for consensus interferon production in \\ E. coli}

The Overnight Express Autoinduction System 1 (Novagen, Darmstadt, Germany) was employed for high-level cIFN- $\alpha$ protein expression by auto-induction from the constructed pET-cIFN $\alpha$ plasmid. The Overnight Express Autoinduction System 1 medium was prepared aseptically by adding $20 \mathrm{ml}$ OnEx solution 1 (induction solution), $50 \mathrm{ml} \mathrm{OnEx}$ solution 2 (buffering solution), and $1 \mathrm{ml} \mathrm{OnEx}$ solution 3 (magnesium solution) to $929 \mathrm{ml}$ sterile LB broth. A single clone was cultured in the Overnight Express Autoinduction System medium supplemented with $100 \mu \mathrm{g} / \mathrm{ml}$ ampicillin in a shaker incubator at $30^{\circ} \mathrm{C}$ and $300 \mathrm{rpm}$. 
After overnight or $24 \mathrm{~h}$ incubation, cells were harvested by centrifugation at $4000 \mathrm{rpm}$ for $15 \mathrm{~min}$ at $4^{\circ} \mathrm{C}$. Each cell pellet collected from $1 \mathrm{ml}$ of the bacterial culture was resuspended in $100 \mu \mathrm{l}$ of $5 \times$ electrophoresis sample buffer, boiled for $10 \mathrm{~min}$, and then loaded onto sodium dodecyl sulfate polyacrylamide gel electrophoresis (SDS-PAGE). Auto-induced cultures were grown and induced at different incubation temperatures $\left(25,30\right.$, and $\left.37^{\circ} \mathrm{C}\right)$ for $24 \mathrm{~h}$, then soluble cell lysates of auto-induced cells were analyzed by SDS-PAGE.

Two immunoassays were performed to confirm the identity of the expressed protein in auto-induction T7 system; enzyme-linked immunosorbent assay (ELISA) and western blot. ELISA was performed as previously described [13,19]. Briefly, ELISA microtiter plate (Costar, Cambridge, USA) was coated with $50 \mu \mathrm{l}$ of total cell lysate at a concentration of $5 \mu \mathrm{g} / \mathrm{ml}$ in carbonate buffer solution ( $\mathrm{pH}$ 9.6) for $24 \mathrm{~h}$ at $4^{\circ} \mathrm{C}$. After washing 5 times with $0.12 \mathrm{M} \mathrm{NaCl}, 0.04 \mathrm{M}$ sodium phosphate, $\mathrm{pH} 7.2$ buffer (PBS), the plate was blocked by adding $100 \mu \mathrm{l}$ of blocking buffer $\left(2 \% \mathrm{w} / \mathrm{v}\right.$ gelatin in PBS) for $1 \mathrm{~h}$ at $37^{\circ} \mathrm{C}$. Then the plate was washed 5 times with PBS and $50 \mu \mathrm{l}$ of monoclonal mouse anti-human IFN- $\alpha$ antibody (PBL InterferonSource, Piscataway, USA) diluted 1:2000 was added to each well. After $1 \mathrm{~h}$ of incubation at $37^{\circ} \mathrm{C}$, the plate was washed 5 times with PBS, and $50 \mu$ of alkaline phosphatase-conjugated anti-mouse IgG (BIO-RAD, Alfred Nobel, Hercules, USA) diluted 1:1000 was added, followed by an incubation of $1 \mathrm{~h}$ at $37^{\circ} \mathrm{C}$. After washing five times, $p$-Nitrophenyl phosphate ( $p$-NPP) was added for color development and optical density was measured at $405 \mathrm{~nm}$ using an ELISA microtiter plate reader (MicroPlate Reader, BIO-RAD, USA). For western blotting, the protein bands were separated on 12\% SDS-PAGE and transferred onto a nitrocellulose membrane in a buffer of $\mathrm{pH} 8.4$ containing $1.93 \mathrm{~g} / \mathrm{L}$ Tris base and $9 \mathrm{~g} / \mathrm{L}$ glycine. Transfer was done for $8 \mathrm{~h}$ at 30 Volt. After transfer, the membrane was blocked using $2 \% \mathrm{w} / \mathrm{v}$ bovine serum albumin (BSA) in PBS for $1 \mathrm{~h}$. After a brief wash with PBS, the membrane was incubated with monoclonal antihuman IFN- $\alpha$ antibody diluted 1:2000 for $1 \mathrm{~h}$ at room temperature with gentle shaking. The membrane was washed again three times with PBS for $10 \mathrm{~min}$ each, and then incubated with anti-mouse IgG-peroxidase conjugate (BIO-RAD, USA) diluted 1:1000 at room temperature for $1 \mathrm{~h}$ with gentle shaking. Washing was done again with the same procedure described above. Protein bands were developed with 3,3 Diaminobenzidine (DAB) [20].

\section{Optimization of auto-induction expression}

To grow the cells to stationary phase $\left(\mathrm{OD}_{600}=6-7\right)$ and optimize the yield of cIFN- $\alpha$ production in auto-induction system, cultures were incubated at different temperatures $\left(25,30\right.$, and $\left.37^{\circ} \mathrm{C}\right)$ and samples were taken at different time points $(8,10,12$, and $24 \mathrm{~h}$ ). Yields of cIFN- $\alpha$ (volumetric yields $(\mathrm{g} / \mathrm{L}))$ were calculated.

\section{Purification}

The supernatant and the pellet (inclusion bodies) of the cell lysate were prepared from 1 liter of optimized autoinduced shake flask culture and then subjected to SDSPAGE analysis as previously described [21]. The cell lysate supernatant was loaded at $1 \mathrm{ml} / \mathrm{min}$ onto a DEAESepharose CL-6B anion-exchange column (Pharmacia Biotech, Uppsala, Sweden) previously equilibrated with $20 \mathrm{mM}$ Tris- $\mathrm{HCl}, \mathrm{pH}$ 8. The column was washed with ten bed volumes of the same buffer (flow rate $2 \mathrm{ml} / \mathrm{min}$ ). The bound proteins were eluted with $100 \mathrm{ml}$ linear gradient of $0-1 \mathrm{M} \mathrm{NaCl}$ generated using AKTAprime plus FPLC protein separator system (GE Healthcare Life Sciences Products, Cardiff, UK) at a flow rate of $1 \mathrm{ml} /$ min. Twenty fractions of $5 \mathrm{ml}$ each were collected. The eluted protein in the fractions was monitored by an online UV detector. Purified cIFN- $\alpha$ protein was analyzed by SDS-PAGE and ELISA. Purified cIFN- $\alpha$ protein content was determined by Lowry method [22]. The endotoxin content was checked [23] to avoid its mitogenic effects on the cell culture system. All cIFN- $\alpha$ preparations used were free of endotoxin (data not shown).

\section{Cell culture}

Hepatoma cell line HepG2 HB-8065 (ATCC, USA) was cultured in RPMI-1640 medium (Lonza, Verviers, Belgium) supplemented with $2 \% \mathrm{v} / \mathrm{v}$ L-glutamine, $10 \%$ $\mathrm{v} / \mathrm{v}$ fetal bovine serum (FBS), and $1 \% \mathrm{v} / \mathrm{v}$ penicillinstreptomycin. The cultures were maintained at $37^{\circ} \mathrm{C}$ in a humidified atmosphere with $5 \% \mathrm{CO}_{2} ; 95 \%$ air in $25 \mathrm{~cm}^{2}$ flasks (Greiner, Frickenhausen, Germany). For subculturing, culture medium was discarded, and then the adherent cells were detached from the surface of the flask using $1 \mathrm{ml}$ of Trypsin-EDTA solution $(0.25 \%$ $\mathrm{w} / \mathrm{v}$ Trypsin- $0.53 \mathrm{mM}$ EDTA) for 5 to $15 \mathrm{~min}$ at $37^{\circ} \mathrm{C}$. The action of Trypsin was stopped by the addition of $3 \mathrm{ml}$ RPMI-1640 medium. The cells were scraped and collected in a $15 \mathrm{ml}$ conical tube, then washed twice by RPMI-1640 supplemented medium, and centrifuged at $1200 \mathrm{rpm}$ for $5 \mathrm{~min}$ at $4^{\circ} \mathrm{C}$ after each wash. The pellet was resuspended in $3 \mathrm{ml}$ RPMI-1640 medium, and then appropriate aliquots of the cell suspension were added to new culture vessels.

\section{Anticancer activity assay}

Recombinant cIFN- $\alpha$ expressed in auto-induction system was tested for anticancer activity against hepatoma cell line HepG2 and compared with commercial recombinant human IFN- $\alpha 2$ a (Shenyang Pharmaceutical Co, Guoyaozhunzi, China) by using 3-(4, 5-dimethylthiazol2-yl)-2, 5-diphenyltetrazolium bromide (MTT) rapid 
colorimetric assay as described by Mosmann [24] and El-Baky et al. [19]. Interferons were diluted with RPMI1640 medium to desired concentrations ( $3,3.33,3.75$, $4.28,5,6,7.5,10,15$ and $30 \mu \mathrm{g} / \mathrm{ml})$. HepG2 cells were seeded in flat-bottomed 96-well cell culture plates at a density of $25 \times 10^{4}$ cells $/ \mathrm{ml}$ in final volume of $200 \mu \mathrm{l}$ RPMI-1640 supplemented medium per well, and incubated for $24 \mathrm{~h}$ at $37^{\circ} \mathrm{C}$ in $5 \% \mathrm{CO}_{2} ; 95 \%$ air. After $24 \mathrm{~h}$, cells were treated with various concentrations of the tested interferons in 4 replicates. After further $24 \mathrm{~h}$, the medium was discarded and cell monolayers were washed with sterile PBS three times. Twenty microliters of $5 \mathrm{mg} / \mathrm{ml}$ MTT solution (Sigma, St. Louis, USA) were added to each well and incubated at $37^{\circ} \mathrm{C}$ for $3 \mathrm{~h}$. The formed insoluble purple formazan product was dissolved with $180 \mu$ l of dimethyl sulfoxide (DMSO). Optical density was measured at $560 \mathrm{~nm}$, and then the percentage of cytotoxicity compared to the untreated cells was determined with the following equation:

$$
\% \text { Cytotoxicity }=\frac{\text { Absorbance of cells without treatment }}{\text { Absorbance of cells without treatment }}
$$

The plot of \% cytotoxicity versus sample concentration was used to calculate the concentration lethal to $50 \%$ of the cells $\left(\mathrm{LD}_{50}\right)$ value.

\section{Isolation of human blood lymphocytes and selectivity index calculation}

The peripheral blood mononuclear cells (PBMCs) were isolated as previously described by Lohr et al. [25] and El-Fakharany et al. [26]. In brief, peripheral blood samples collected from a single healthy volunteer were diluted with 5 volumes of a freshly prepared red blood cell (RBC) lysis buffer of $\mathrm{pH} 8$ containing $38.8 \mathrm{mM} \mathrm{NH}_{4} \mathrm{Cl}$, $2.5 \mathrm{mM} \mathrm{KHCO}_{3}$, and $1 \mathrm{mM}$ EDTA, incubated at room temperature for $10 \mathrm{~min}$ and centrifuged at $1500 \mathrm{rpm}$ for $5 \mathrm{~min}$. The nucleated cells were precipitated and washed with PBS. Proliferation of human lymphocytes in response to the tested interferons was assessed by MTT assay. The selectivity index (SI) value was calculated from the $\mathrm{LD}_{50}$ ratio in lymphocytes over HepG2 cells. The SI value indicates the selectivity of interferon samples to the HepG2 cell line [27].

\section{Antiviral assay}

The antiviral activity of the tested interferons was determined using cytopathic effect (CPE) assay against herpes simplex virus 1 (HSV-1) as reported by Rashad et al. [28]. Vero cells grown to confluency in 96-well plates were infected with $100 \mu \mathrm{l}$ of stock virus. After an adsorption period of $2 \mathrm{~h}$ at $37^{\circ} \mathrm{C}$, virus was removed and the following concentrations of the tested interferons were added: $0.003,0.03,0.3,3$, and $30 \mu \mathrm{g} / \mathrm{ml}$ for recombinant
cIFN- $\alpha$ and $0.1,1,10,100$, and $1000 \mathrm{IU} / \mathrm{ml}$ for commercial IFN- $\alpha 2 a$, then maintenance Dulbecco's modified Eagle medium (DMEM) with $2 \% \mathrm{v} / \mathrm{v}$ FBS was added $\left(100 \mu \mathrm{l} /\right.$ well). The cultures were further incubated at $37^{\circ} \mathrm{C}$ for $24 \mathrm{~h}$, until complete CPE was observed in the infected and untreated virus control. The determination of the anti-HSV-1 activity of the tested interferons was based on virus-induced cytopathogenicity of HSV-1 on Vero cells, measured at day 2 post virus infection by the MTT colorimetric method. An absorbance of formazan was detected at $560 \mathrm{~nm}$. The results were expressed as the $50 \%$ effective concentration $\left(\mathrm{EC}_{50}\right)$. The $\mathrm{EC}_{50}$ was defined as the interferon concentration required for protecting $50 \%$ of the virus-infected cells against viral cytopathogenicity. The concentrations of recombinant cIFN- $\alpha$ and commercial IFN- $\alpha 2 \mathrm{a}$ which exhibited $50 \%$ cytotoxicity $\left(\mathrm{LD}_{50}\right)$ were also determined. The therapeutic index was calculated by dividing $\mathrm{LD}_{50}$ on $\mathrm{EC}_{50}$.

\section{Statistical analysis}

Differences between the variants were tested using Student's $t$-test and McNemar's test [29]. A $P$-value of $<0.05$ was considered statistically significant.

\section{Results}

\section{Plasmid construction for auto-induction expression}

The blunt-ended PCR product of the synthetic gene coding for cIFN- $\alpha$ was directionally cloned into pET101/DTOPO vector by adding four bases (CACC) to the forward primer. The overhang in the vector (GTGG) invades the 5 ' end of the PCR product, anneals to the added bases, and stabilizes the PCR product in the correct orientation. The constructed pET-cIFN $\alpha$ plasmid was transformed into $E$. coli BL21 (DE3) for cIFN- $\alpha$ auto-induction expression under the control of the T7 promoter. One transformant harbored recombinant pET-CIFN $\alpha$ was analyzed by restriction digestion to confirm the presence of the insert and nucleotide sequencing. The sequencing data indicated that the transformant carried the correct construct (data not shown). As showed in Figure 1, the construct has the correct sized cIFN- $\alpha$ gene.

\section{Expression of consensus interferon by auto-induction}

The recombinant human cIFN- $\alpha$ protein was overexpressed in auto-induced cultures using the pET system and lactose as inducer. After separation by $12 \%$ SDSPAGE, total proteins obtained from auto-induced cells contained a thick protein band of about $19 \mathrm{kDa}$ size, corresponding to the calculated size of cIFN- $\alpha$ protein (Figure 2A, lanes 3 and 4). SDS-PAGE analysis of crude proteins from auto-induced cultures or cultures induced by IPTG revealed that the auto-induced cultures yielded more cIFN- $\alpha$ protein than IPTG-induced cultures (Figure 2A, lanes 2-4). Figure 2A, lane 3 shows that maximum 


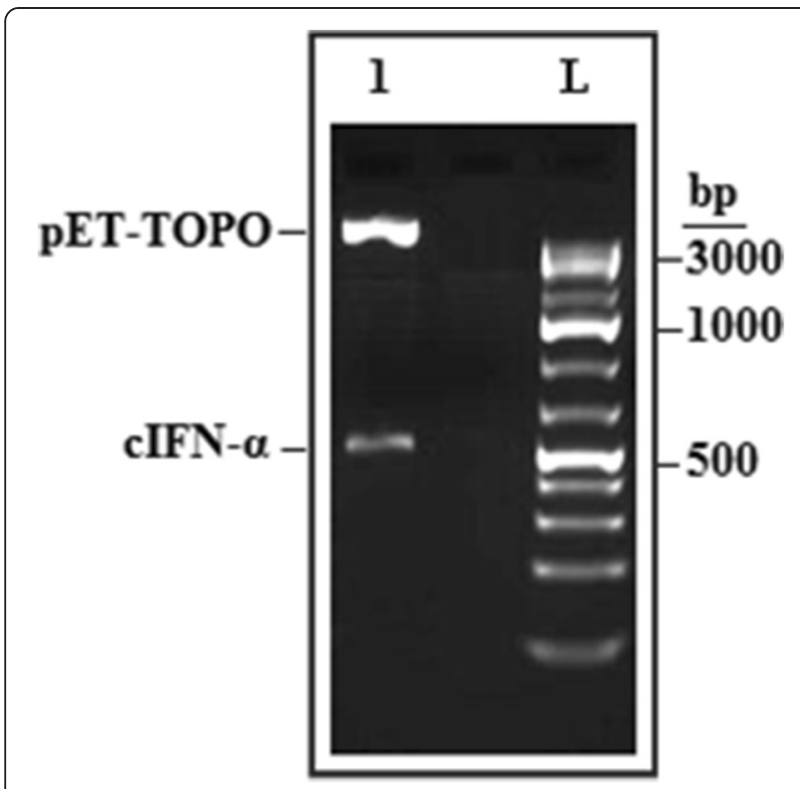

Figure $1 \mathrm{~A} 2 \%$ agarose gel showing the result of restriction digestion of recombinant $\mathrm{pET}$-cIFNa. Recombinant pET-CIFNa was digested overnight at $37^{\circ} \mathrm{C}$ using $\mathrm{Xbal}$ and Sacl enzymes. Lane 1 shows the PET-TOPO vector fragment $(5.73 \mathrm{~kb})$ and the CIFN- $a$ band (534 bp, with $26 \mathrm{bp}$ added to the actual size of the gene from the vector cloning site and $10 \mathrm{bp}$ introduced by gene-specific primers in the gene to enable $\mathrm{pET}$ directional TOPO cloning). L pointed GeneRuler 100 bp Plus DNA Ladder. expression was reached by incubation of auto-induced cultures for $24 \mathrm{~h}$ at $30^{\circ} \mathrm{C}$. Lowering incubation temperature to $25^{\circ} \mathrm{C}$ or $30^{\circ} \mathrm{C}$ improved the yield of soluble cIFN- $\alpha$ protein (Figure $2 \mathrm{~B}$ ). The effects of temperature and length of incubation on cIFN- $\alpha$ production level in auto-induction system are demonstrated in Figure 3.

The identity of the overexpressed protein was verified by ELISA using monoclonal anti-human IFN- $\alpha$ antibody as presented in Table 1. The cIFN- $\alpha$ activity of cellular extract prepared from auto-induced E. coli BL21 (DE3) cells was presented as the mean \pm standard deviation (SD) of three replicates. As demonstrated in Table 1, the mean absorbance values for cIFN- $\alpha$ in auto-induced cells and IFN- $\alpha 2$ a were respectively $0.637 \pm 0.022$ and $0.934 \pm$ 0.016 , compared with the value of cIFN- $\alpha$ in cellular extract prepared from uninduced cells as negative control of $0.046 \pm 0.008$. A significant difference $(P<0.05)$ in ELISA signals was found between commercial IFN- $\alpha 2 \mathrm{a}$ or recombinant cIFN- $\alpha$ in auto-induced cells and the negative control. ELISA results revealed that the autoinduced cultures yielded more cIFN- $\alpha$ protein than IPTGinduced cultures. Western blot analysis of expressed protein revealed that recombinant cIFN- $\alpha$ expressed in auto-induced cells was strongly and specifically recognized by monoclonal anti-human IFN- $\alpha$ antibody at the expected $19 \mathrm{kDa}$ molecular weight (Figure 4).

\section{Purification of expressed CIFN- $a$}

Both the supernatant and the pellet of the cell lysate after sonication were examined by SDS-PAGE to detect the solubility of expressed cIFN- $\alpha$ protein. As shown in
(A)

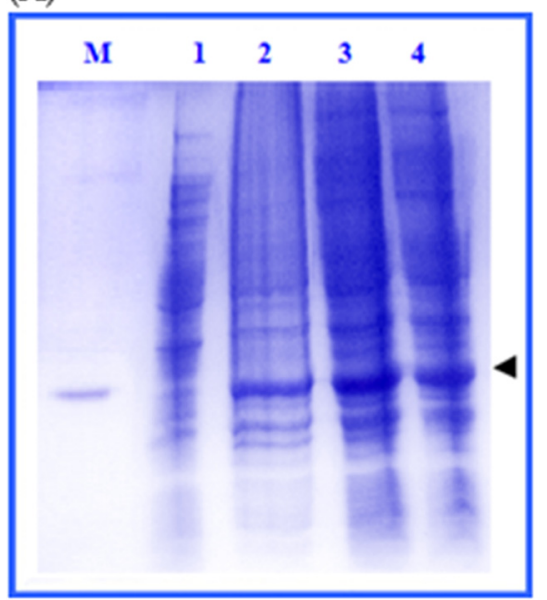

(B)

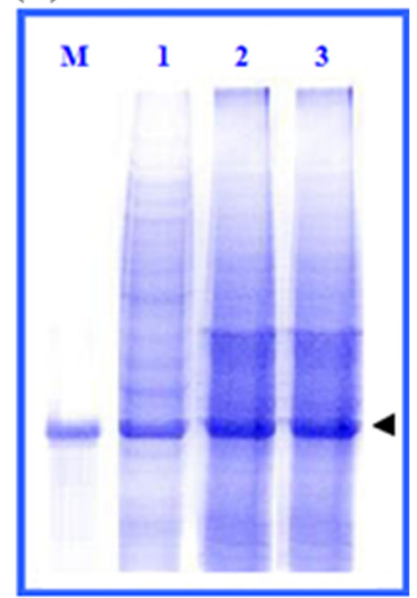

Figure 2 SDS-PAGE analysis of auto-induction expression of cIFN-a. (A) Auto-induction expression of CIFN- $a$ at $30^{\circ} \mathrm{C}$ for 12 and $24 \mathrm{~h}$. Lane M: commercial IFN-a2a as molecular weight marker of 19,2 kDa size. Lane 1: total proteins from uninduced cells. Lane 2: total proteins from IPTG-induced cells. Lane 3: total proteins from auto-induced cells after $24 \mathrm{~h}$ incubation at $30^{\circ} \mathrm{C}$. Lane 4: total proteins from auto-induced cells after overnight incubation at $30^{\circ} \mathrm{C}$. (B) Auto-induction expression of soluble CIFN-a. Lane M: commercial IFN-a2a as molecular weight marker of $19,2 \mathrm{kDa}$ size. Lanes $1-3$, soluble cell lysates of auto-induced cells after $24 \mathrm{~h}$ incubation at $37^{\circ} \mathrm{C}, 30^{\circ} \mathrm{C}$, and $25^{\circ} \mathrm{C}$, respectively. The arrow heads pointed the position of CIFN-a. 

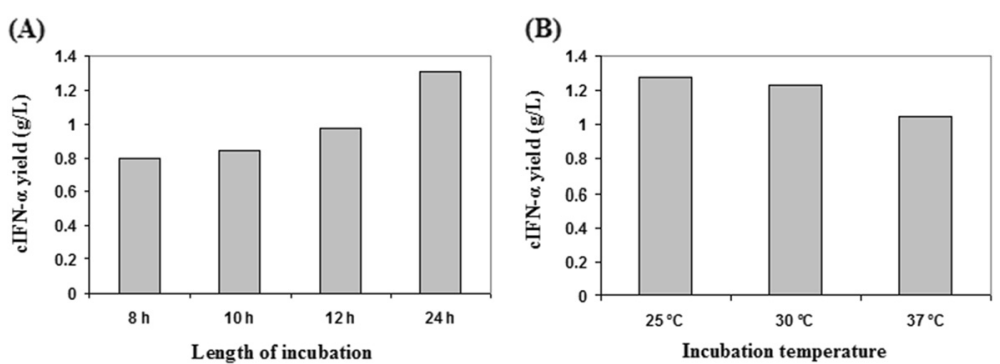

Figure 3 Time and temperature optimization of CIFN-a auto-induction expression. (A) Time optimization of clFN-a auto-induction expression. Cultures were incubated for $8,10,12$, and $24 \mathrm{~h}$ at $30^{\circ} \mathrm{C}$. (B) Temperature optimization of cIFN-a auto-induction expression. Cultures were incubated at 25,30 , and $37^{\circ} \mathrm{C}$ for $24 \mathrm{~h}$.

Figure 5, the main fraction of cIFN- $\alpha$ produced in autoinduction system was found in the soluble form after $24 \mathrm{~h}$ of incubation at $25^{\circ} \mathrm{C}$ or $30^{\circ} \mathrm{C}$. Yields of cIFN- $\alpha$ in different cell preparations are reported in Table 2.

Our strategy for purifying expressed cIFN- $\alpha$ in autoinduction system involved separation of the soluble fraction of cell lysate and purification of cIFN- $\alpha$ by ion-exchange chromatography. The cell lysate supernatant was loaded onto a DEAE-Sepharose column previously equilibrated with $20 \mathrm{mM}$ Tris- $\mathrm{HCl}, \mathrm{pH} 8$. After washing, the bound proteins were eluted with $100 \mathrm{ml}$ linear gradient of $0-1 \mathrm{M} \mathrm{NaCl}$. The elution profile of cIFN- $\alpha$ is shown in Figure 6A. Figure 6B shows SDS-PAGE profile of samples before and after cIFN- $\alpha$ purification. ELISA analysis of samples before (cell lysate supernatant containing cIFN- $\alpha$ ) and after CIFN- $\alpha$ purification indicated that there is a significant difference $(P<0.05)$ in ELISA signals between the cell lysate supernatant containing cIFN- $\alpha$ (mean OD at $405 \mathrm{~nm} \pm$ SD was $0.476 \pm 0.023$ ) and the purified cIFN- $\alpha$ (mean OD at $405 \mathrm{~nm} \pm \mathrm{SD}$ was $0.851 \pm 0.009$ ). The data revealed that cIFN- $\alpha$ was purified to near homogeneity, utilizing single-step ion-exchange chromatography on DEAE-Sepharose from cell lysate supernatant. The yield was $270 \mathrm{mg}$ of purified cIFN- $\alpha$ from 1 liter of shake flask culture as estimated by Lowry method which is much higher than IPTG-inducible T7 expression system

Table 1 Reactivity of monoclonal anti-human IFN-a antibody against recombinant cIFN- $\alpha$ expressed in $E$. coli BL21 (DE3) cells by auto-induction

\begin{tabular}{ll}
\hline Sample & OD at $405 \mathrm{~nm}$ (mean \pm SD) \\
\hline Commercial IFN-a2a & $0.934 \pm 0.016$ \\
Recombinant CIFN-a (uninduced cells) & $0.046 \pm 0.008^{\mathrm{a}}$ \\
Recombinant CIFN-a (IPTG-induced cells) & $0.447 \pm 0.014^{\mathrm{b}}$ \\
Recombinant CIFN-a (auto-induced cells) & $0.637 \pm 0.022^{\mathrm{a}, \mathrm{b}}$ \\
\hline
\end{tabular}

${ }^{a}$ Monoclonal anti-human IFN- $a$ antibody reacted significantly $(P<0.05)$ with expressed cIFN- $a$ protein in auto-induced cells.

${ }^{\mathrm{b}} \mathrm{A}$ significant difference $(P<0.05)$ in ELISA signals was found between recombinant cIFN- $a$ in auto-induced cells and recombinant cIFN-a in IPTG-induced cells.

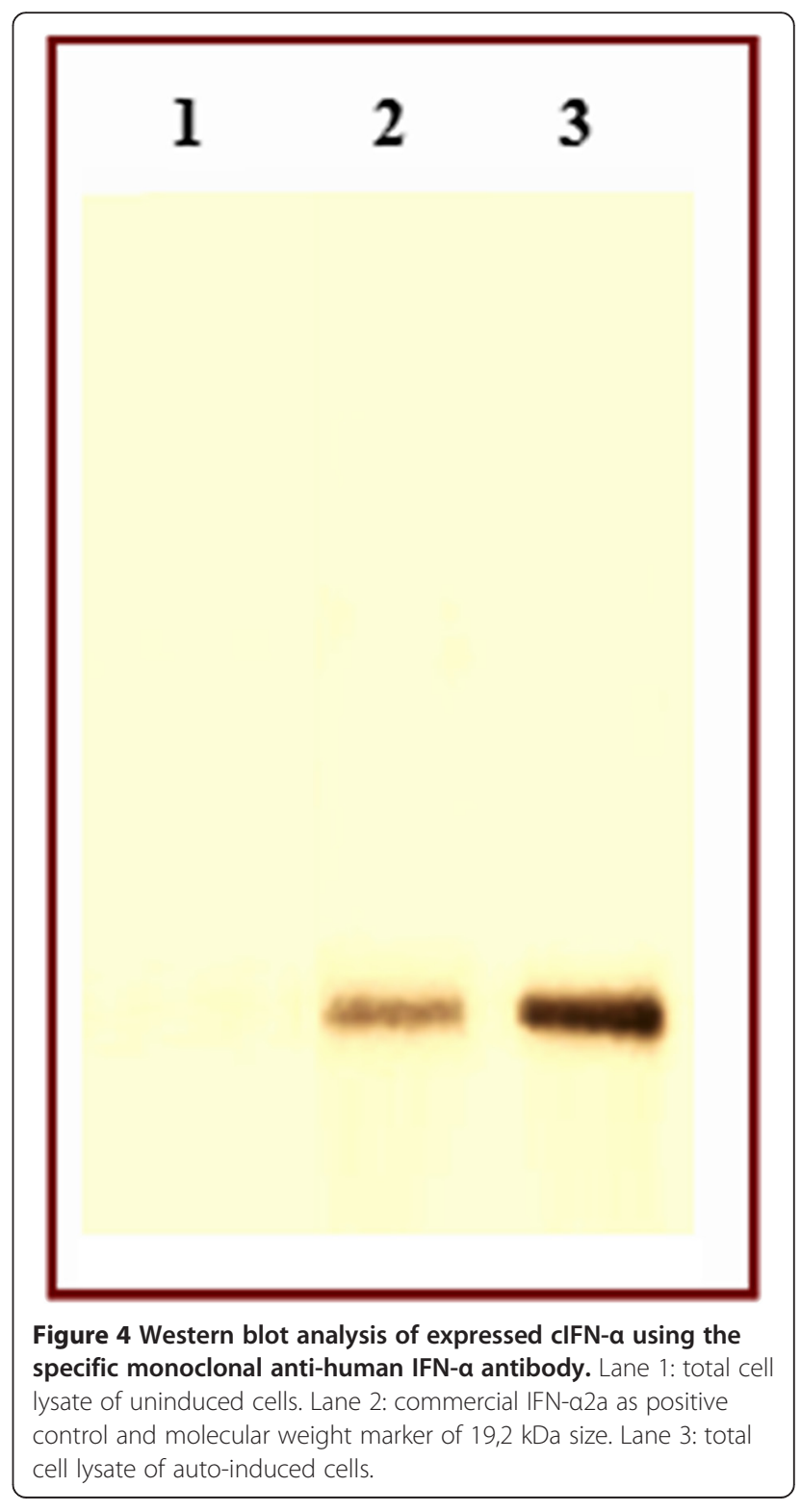




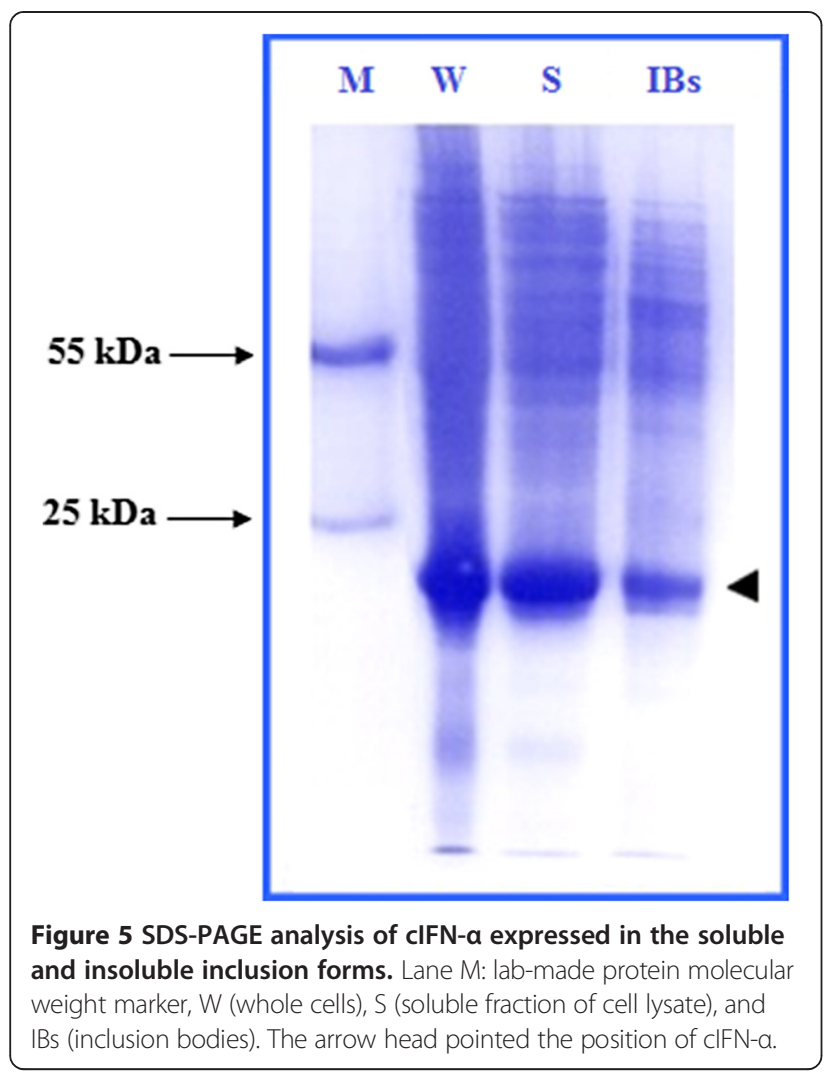

that yielded $150 \mathrm{mg} / \mathrm{L}$ (unpublished results) and heatinducible expression system that achieved a yield of $70 \mathrm{mg} / \mathrm{L}$ (as we have previously reported). These results suggest that auto-inducing media achieved 1.8- and 3.8 -fold higher recombinant cIFN- $\alpha$ protein yield than IPTG-inducible T7 expression system and heat-inducible expression system, respectively.

\section{Anticancer activity of cIFN-a expressed by auto-induction} To evaluate the anticancer (antiproliferative) activity of recombinant cIFN- $\alpha$ and commercial IFN- $\alpha 2 \mathrm{a}$, the inhibitory effect on hepatoma cell line HepG2 was studied using MTT colorimetric assay. The amount of formazan produced by HepG2 cells treated with different concentrations of the tested interferons was compared with the amount of formazan produced by untreated cells, the efficiency of tested interferons in causing death

Table 2 Yields of cIFN-a expressed in optimized auto-induction system

\begin{tabular}{ll}
\hline Sample & clFN-a yield (g/L) \\
\hline Total cell protein & 1.24 \\
Total cell lysate & 1.08 \\
Soluble cell lysate & $0.76^{\mathrm{a}}(70.37 \%)$ \\
Solubilized inclusion bodies & $0.217(20.09 \%)$ \\
\hline
\end{tabular}

${ }^{a}$ Majority of the expressed cIFN-a protein was in the cell lysate supernatant (about $70 \%$ of the yield in total cell lysate). or changing metabolism of cancer cells could be deduced through the significant decrease in the absorbance of purple formazan product at $560 \mathrm{~nm}$ after $24 \mathrm{~h}$ from treatment with various concentrations of samples.

The results were expressed as percentage of cytotoxicity compared with the untreated cells. The relationship between percent cytotoxicity and the sample concentration is illustrated in Figure 7. This plot of \% cytotoxicity versus sample concentration was used to calculate $\mathrm{LD}_{50}$. Recombinant cIFN- $\alpha$ and commercial IFN- $\alpha 2 a$ demonstrated a potent inhibitory (antiproliferative) effect on HepG2 cell line after $24 \mathrm{~h}$ of treatment; $\left(\mathrm{LD}_{50}=2.79 \mu \mathrm{g} / \mathrm{ml}\right.$ and $\mathrm{LD}_{50}=4.16 \mu \mathrm{g} / \mathrm{ml}$, respectively). This was equivalent to $33 \%$ (1.5-fold) enhancement in activity. Figure 7 clearly demonstrated the superior anticancer activity of cIFN- $\alpha$ over the commercial IFN- $\alpha 2 \mathrm{a}$.

\section{Selectivity index calculation}

The effect of cIFN- $\alpha$ and IFN- $\alpha 2 a$ on the proliferation of human lymphocytes was evaluated after $24 \mathrm{~h}$ incubation by MTT assay (Figure 8 ). Both interferons showed significantly lower antiproliferative activity $(P<0.05)$ against PBMCs than that against HepG2 cells. The SI values were calculated using the ratio:

$$
\begin{aligned}
\mathrm{SI}= & \mathrm{LD}_{50} \text { of tested samples in normal cell (lymphocyte) } \\
& \div \mathrm{LD}_{50} \text { of tested samples in HepG } 2 \text { cells. }
\end{aligned}
$$

The SI values for cIFN- $\alpha$ and IFN- $\alpha 2 \mathrm{a}$ were 3.81 and 2.44 , respectively. Recombinant cIFN- $\alpha$ showed a significantly higher selectivity $(P<0.05)$ to HepG2 cells than selectivity to HepG2 cells observed in case of commercial IFN- $\alpha 2 \mathrm{a}$.

\section{Antiviral activity assay}

The antiviral potency of recombinant cIFN- $\alpha$ and commercial IFN- $\alpha 2$ a was determined via an in vitro assay, by using Vero cells challenged with HSV-1. The results were expressed as $\mathrm{EC}_{50}$. The $\mathrm{EC}_{50}$ value for recombinant cIFN- $\alpha$ was $30.85 \mathrm{ng} / \mathrm{ml}$. Protection obtained with a total of $30.85 \mathrm{ng} / \mathrm{ml}$ of recombinant $\mathrm{cIFN}-\alpha$ was equivalent to the protection afforded by $100.35 \mathrm{IU} / \mathrm{ml}$ of commercial IFN- $\alpha 2 \mathrm{a}$. The $\mathrm{EC}_{50}, \mathrm{LD}_{50}$, and therapeutic index values for cIFN- $\alpha$ and IFN- $\alpha 2 \mathrm{a}$ are presented in Table 3. Based on the definition of cIFN- $\alpha$ unit as the ability to protect $50 \%$ of cells from HSV-1-induced cytopathogenicity, it was calculated that the final purified cIFN- $\alpha$ has specific antiviral activity of $3.25 \times 10^{6} \mathrm{IU} / \mathrm{mg}$ protein as determined by cytopathogenicity assay; the units were determined using commercial IFN- $\alpha 2 \mathrm{a}$.

\section{Discussion}

Consensus interferon is a synthetic interferon that reflects most of the human type I interferons. This interferon 


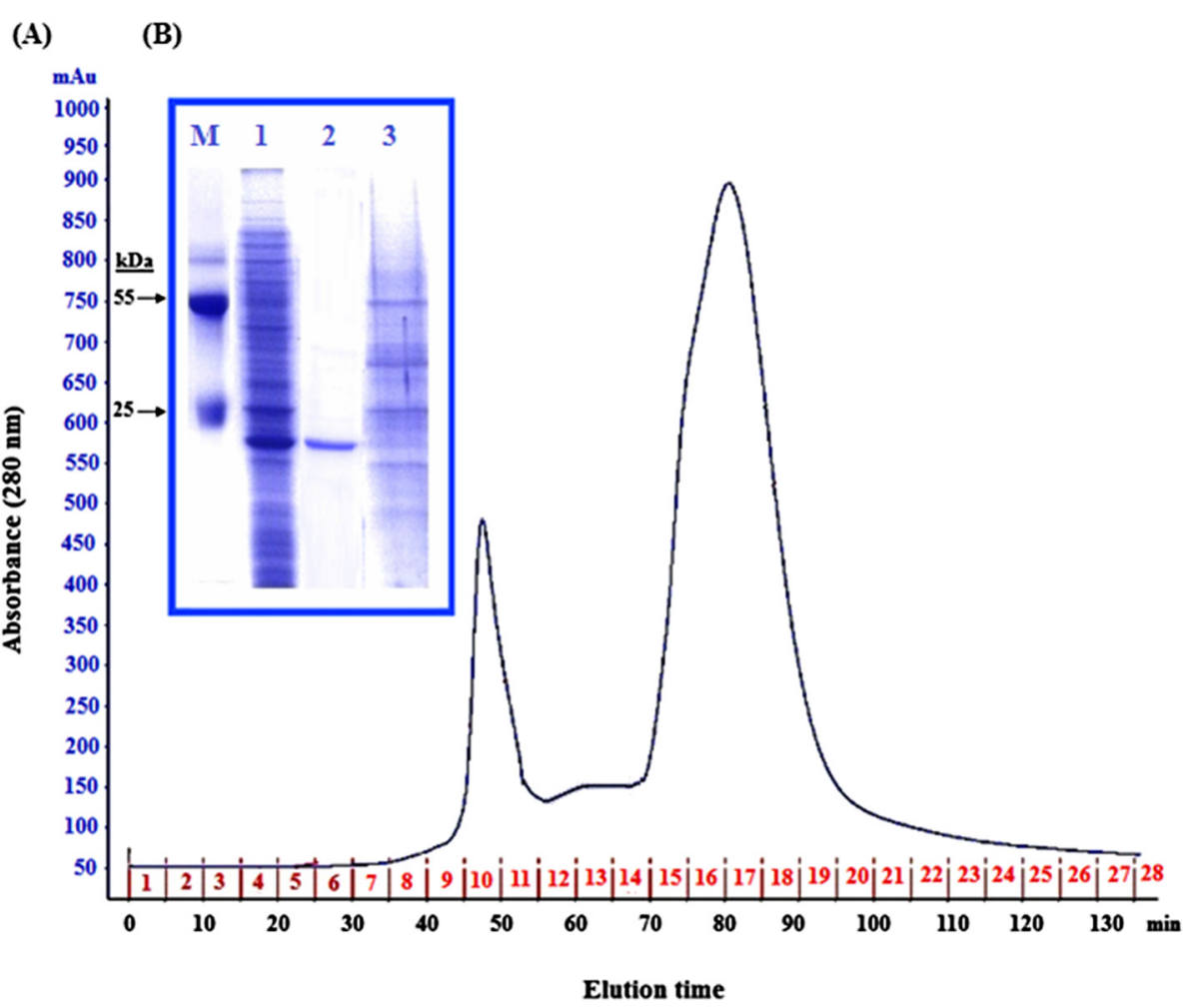

Figure 6 FPLC purification of recombinant cIFN-a expressed in auto-induction system on a DEAE-Sepharose column. (A) Protein elution profile (chromatogram). The profile clearly showed three peaks (fractions 8-11, 12-14, and 15-20). Numbers 1-28: number of collected fractions. (B) SDS-PAGE analysis of samples before and after cIFN-a purification. Lane M: lab-made protein molecular weight marker. Lane 1: cell lysate supernatant of auto-induced cells after $24 \mathrm{~h}$ incubation at $30^{\circ} \mathrm{C}$. Lane 2: recovered CIFN-a protein after purification. Lane 3: cell lysate supernatant of uninduced cells.
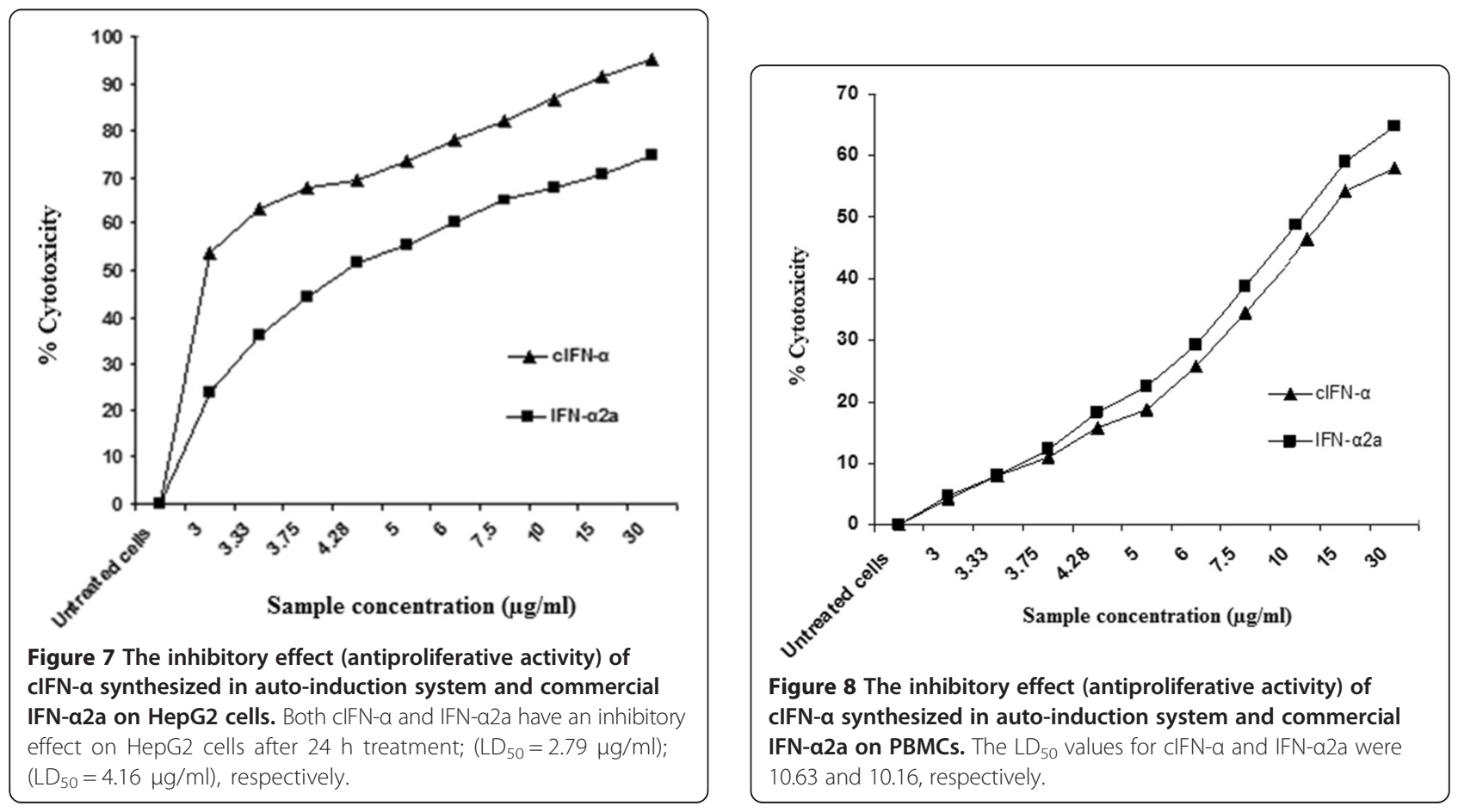
Table $3 \mathrm{LD}_{50}, \mathrm{EC}_{50}$ and therapeutic index values of recombinant CIFN- $a$ determined via an in vitro assay, by using Vero cells challenged with HSV-1

\begin{tabular}{llll}
\hline Interferon & $\mathrm{LD}_{\mathbf{5 0}}$ & $\mathrm{EC}_{\mathbf{5 0}}$ & $\begin{array}{l}\text { Therapeutic } \\
\text { index }\left(\mathrm{LD}_{\mathbf{5 0}} / \mathrm{EC}_{\mathbf{5 0}}\right)\end{array}$ \\
\hline Recombinant CIFN-a & $12.68 \mu \mathrm{g} / \mathrm{ml}$ & $30.85 \mathrm{ng} / \mathrm{ml}$ & 411.02 \\
Commercial IFN-a2a & $992.81 \mathrm{IU} / \mathrm{ml}$ & $100.35 \mathrm{IU} / \mathrm{ml}$ & 9.89 \\
\hline
\end{tabular}

demonstrates a higher biological capacity in vitro. Consensus interferon has been used internationally in treatment of patients with chronic hepatitis $\mathrm{C}$ who fail to respond to conventional IFN- $\alpha$ therapy or those who relapse after treatment cessation [30].

We have previously used a heat-inducible, phage $\lambda \mathrm{P}_{\mathrm{L}}$ promoter-based expression system for high-level expression of recombinant human cIFN- $\alpha$ in shake flask $E$. coli cultures [13]. This system is highly productive, avoids the use of chemical inducers and is easily scalable. However, heat shock and high expression rates resulted in accumulation of the expressed protein into insoluble aggregates in a misfolded and biologically inactive form. Although insoluble misfolded cIFN- $\alpha$ was successfully refolded and purified, in vitro refolding yielded reduced amounts of biologically active product $(70 \mathrm{mg} / \mathrm{L})$. In another study, we reported synthesis of consensus interferon in cell-free extracts after 2-6 h [19]. Reaction conditions were altered to solve insolubility problems. The cell-free system achieved high-yield expression (400 $\mathrm{\mu g} / \mathrm{ml}$ after purification process, which can be scaled up), and remarkably was able to efficiently support the complete maturation of $\operatorname{cIFN}-\alpha$. While cellfree protein synthesis proposes several advantages over cell-based methods, this system is not suitable for largescale protein production. In the present study, we focused on avoiding the problems associated with the use of IPTG induction or heat induction for high-level expression of $c I F N-\alpha$ through the application of autoinducing media to achieve higher biologically active product yields.

The results showed that the auto-induction system in which lactose was used as inducer produced higher cIFN- $\alpha$ yield than those with IPTG addition $(150 \mathrm{mg} / \mathrm{L})$ or heat induction $(70 \mathrm{mg} / \mathrm{L})$. We obtained $270 \mathrm{mg}$ highly purified soluble cIFN- $\alpha$ protein from 1 liter of batch shake flask culture, which is the highest reported yield according to available data with the exception of the yield reported by Babu et al. [31] which was $300 \mathrm{mg}$ of purified recombinant human IFN- $\alpha$ obtained from 1 liter of high cell density fed-batch $E$. coli culture. This can be explained by the fact that lactose is not only an inducer but also serves as a source of carbon and energy. In contrast, when IPTG is used as an inducer, the cells experience nutrient starvation, affecting protein expression. In addition, heat induction leads to formation of inclusion bodies that need in vitro refolding before purification which increases downstream product loss.

The synthesized cIFN- $\alpha$ in auto-induction system was biologically active as confirmed by its anticancer and antiviral effects. The anticancer effect of cIFN- $\alpha$ exceeds that of the monotype interferon (IFN- $\alpha 2 a$ ), with higher selectivity to the tested cancer cell line, which may agree with the previous results of antiproliferative effect of consensus interferon in comparison to that of natural recombinant alpha interferons [6]. Purified cIFN- $\alpha$ has specific antiviral activity of $3.25 \times 10^{6} \mathrm{IU} / \mathrm{mg}$ protein.

\section{Conclusions}

In this study, higher product yield was achieved by using the auto-induction process for production of cIFN- $\alpha$ protein in E. coli. Auto-induction can be applied to increase the yield of other therapeutic recombinant proteins whose expression in E. coli using conventional expression systems is still challenging.

\section{Abbreviations}

BSA: Bovine serum albumin; cIFN-a: Human consensus interferon-alpha; CPE: Cytopathogenicity effect; DAB: 3,3 Diaminobenzidine; DCW: Dry cell weight; DMEM: Dulbecco's modified Eagle medium; DMSO: Dimethyl sulfoxide; $\mathrm{EC}_{50}$ : 50\% effective concentration; ELISA: Enzyme-linked immunosorbent assay; FBS: Fetal bovine serum; HSV-1: Herpes simplex virus 1; IFNs: Interferons; IPTG: Isopropyl- $\beta-D-1$-thiolgalactopyranoside; LB: Luria Bertani; LD 50 : Concentration lethal to $50 \%$ of the cells; MTT: 3-(4, 5dimethylthiazol-2-yl)-2, 5-diphenyltetrazolium bromide; PBMCs: Peripheral blood mononuclear cells; p-NPP: p-Nitrophenyl phosphate; RBC: Red blood cell; SDS-PAGE: Sodium dodecyl sulfate polyacrylamide gel electrophoresis; SI: Selectivity index.

\section{Competing interests}

The authors declare that they have no competing interest.

\section{Authors' contributions}

NAE participated in experiments design, carried out the experiments, and wrote the draft. MHL collected the literature, organized it, and participated in statistical data analysis. EMR conceived the study, participated in its design and coordination, providing advice, criticism and final editing of the manuscript. All authors read and approved the final manuscript.

\section{Acknowledgements}

This study was funded by the Science and Technology Development Fund (STDF-ID269) for EMR.

\section{Author details}

${ }^{1}$ Therapeutic and Protective Proteins Laboratory, Protein Research Department, Genetic Engineering and Biotechnology Research Institute, City for Scientific Research and Technology Applications, New Borg EL-Arab, 21934 Alexandria, Egypt. ${ }^{2}$ College of Applied Medical Sciences, King Abdulaziz University, P.O. Box 80203, Jeddah 21589, Saudi Arabia. ${ }^{3}$ Biological Sciences Department, Faculty of Science, King Abdulaziz University, P.O. Box 80203, Jeddah 21589, Saudi Arabia.

Received: 4 September 2014 Accepted: 18 February 2015

Published online: 06 March 2015

\section{References}

1. Stewart IWE. The Interferon System. New York: Springer; 1979.

2. DeMaeyer E, DeMaeyer-Guignard J. Interferons and Other Regulatory Cytokines. Inc: John Wiley and Sons; 1988.

3. Pestka S, Langer JA, Zoon KC, Samuel CE. Interferons and Their Actions. Annu Rev Biochem. 1987;56:727-77. 
4. Pestka S, Baron S. Definition and classification of the interferons. Methods Enzymol. 1981;78:3-14.

5. Blatt LM, Davis JM, Klein SB, Taylor MW. The biological activity and molecular characterization of a novel synthetic interferon-alpha species, consensus-interferon. J Interferon Cytokine Res. 1996;16:489-99.

6. Ozes ON, Reiter Z, Klein S, Blatt LM, Taylor MW. A comparison of interferon-Con 1 with natural recombinant interferons alpha: antiviral, antiproliferative, and natural killer-inducing activities. J Interferon Res. 1992;12:55-9.

7. Cornberg M, Hadem J, Herrmann E, Schuppert F, Schmidt HH, Reiser M, et al. Treatment with consensus interferon (CIFN) plus ribavirin in non-responder patients with chronic hepatitis C: a randomized open-label pilot study. J Hepatol. 2006;44:291-301.

8. Kaiser S, Hass H, Lutze B, Gregor M. Comparison of daily consensus interferon versus peginterferon alfa-2a extended therapy of 72 weeks for peginterferon/ribavirin relapse patients with chronic hepatitis $C$ [abstract]. J Gastroenterol. 2006;130:S1060

9. Alton K, Stabinsky Y, Richards R, Ferguson B, Goldstein L, Altrock B, et al. Production, characterization and biological effects of recombinant DNA derived human IFN- $a$ and IFN- $\gamma$ analogs. In: De Maeyer E, Schellekens H, editors. The Biology of the Interferon System. Amsterdam: Elsevier; 1983. p. 119-28.

10. Fieschkoa J, Ritch T. Production of human alpha consensus interferon in recombinant Escherichia coli. Chemical Engineer Commun. 1986;45:229-40.

11. Klein ML, Bartley TD, Lai PH, Lu HS. Structural Characterization of Recombinant Consensus Interferon-a. J Chromatogr. 1988;454:205-15.

12. Curless C, Fu K, Swank R, Fieschko J, Tsai L. Design and evaluation of a two stage, cyclic, recombinant fermentation process. Biotechnol Bioeng. 1991;38:1082-90

13. Mohammed Y, El-Baky NA, Redwan EM. Expression, purification, and characterization of recombinant human consensus interferon-alpha in Escherichia coli under $\lambda P_{L}$ promoter. Prep Biochem Biotechnol. 2012;42:426-47.

14. Studier FW, Moffatt BA. Use of bacteriophage T7 RNA polymerase to direct selective high-level expression of cloned genes. J Mol Biol. 1986;189:113-30.

15. Dubendorff JW, Studier FW. Controlling basal expression in an inducible T7 expression system by blocking the target $\mathrm{T} 7$ promoter with lac repressor. J Mol Biol. 1991;219:45-59.

16. Lin WJ, Huang SW, Chou CP. DegP-coexpression minimizes inclusion-body formation upon overproduction of recombinant penicillin acylase in Escherichia coli. Biotechnol Bioeng. 2001;73:484-92.

17. Studier FW. Protein production by auto-induction in high density shaking culture. Protein Expr Purif. 2005;41:207-34.

18. Redwan EM, Matar SM, El-Aziz GA, Serour EA. Synthesis of the human insulin gene: Protein expression, scaling up and bioactivity. Prep Biochem Biotechnol. 2008;38:24-39.

19. EL-Baky NA, Omar SH, Redwan EM. The anti-cancer activity of human consensus interferon-alpha synthesized in cell-free system. Protein Expr Purif. 2011:80:61-7.

20. Almehdar HA, Adel-Sadek MA, Redwan EM. Immunoreactivity and two-dimensional gel-electrophoresis characterization of Egyptian cobra venom proteome. Pak J Pharm Sci. 2015;28:59-64.

21. Mohammed Y, El-Baky NA, Redwan NA, Redwan EM. Expression of human interferon-a8 synthetic gene under $P_{B A D}$ Promoter. Biochemistry (Mosc). 2012:77:1210-9.

22. Lowry OH, Rosebrough NJ, Farr AL, Randall RJ. Protein measurement with the Folin phenol reagent. J Biol Chem. 1951;193:265-75.

23. Redwan EM. Simple, sensitive and quick protocol to detect less than $1 \mathrm{ng}$ of bacterial lipopolysaccharide. Prep Biochem Biotechnol. 2012;42:171-82.

24. Mosmann T. Rapid colorimetric assay for cellular growth and survival: application to proliferation and cytotoxicity assays. J Immunol Meth. 1983;65:55-63.

25. Lohr HF, Goergen B, Meyer zum Buschenfelde KH, Gerken G. HCV replication in mononuclear cells stimulates anti-HCV-secreting B cells and reflects nonresponsiveness to interferon-alpha. J Med Virol. 1995;46:314-20.

26. El-Fakharany EM, Haroun BM, Ng TB, Redwan ER. Oyster mushroom laccase inhibits hepatitis $C$ virus entry into peripheral blood cells and hepatoma cells. Protein Pept Lett. 2010;17:1031-9.

27. El-Fakharany EM, Tabll A, El-Wahab AA, Haroun BM, Redwan EM. Potential activity of camel milk-amylase and lactoferrin against hepatitis $C$ virus infectivity in HepG2 and lymphocytes. Hepatitis Monthly. 2008;8:101-9.
28. Rashad AE, Shamroukh AH, Abdel-Megeid RE, Mostafa A, El-Shesheny R, Kandeil A, et al. Synthesis and screening of some novel fused thiophene and thienopyrimidine derivatives for anti-avian influenza virus ( $\mathrm{H} 5 \mathrm{~N} 1$ ) activity. Eur J Med Chem. 2010;45:5251-7.

29. Conover WJ. Practical nonparametric statistic. 2nd ed. New York: John Wiley and Sons; 1971.

30. El-Baky NA, Redwan EM. Therapeutic alpha-interferons protein: structure, production, and biosimilar. Prep Biochem Biotechnol. 2015;45:109-27.

31. Babu KR, Swaminathan S, Marten S, Khanna N, Rinas U. Production of interferon-alpha in high cell density cultures of recombinant Escherichia coli and its single step purification from refolded inclusion body proteins. Appl Microbiol Biotechnol. 2000;53:655-60.

\section{Submit your next manuscript to BioMed Central and take full advantage of:}

- Convenient online submission

- Thorough peer review

- No space constraints or color figure charges

- Immediate publication on acceptance

- Inclusion in PubMed, CAS, Scopus and Google Scholar

- Research which is freely available for redistribution 